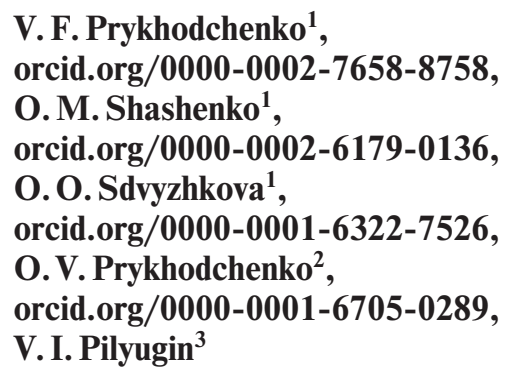

1 - Dnipro University of Technology, Dnipro, Ukraine, e-mail: prykhodchenko.v.f@nmu.one

2 - Institute of Geotechnical Mechanics named by N. Poljakov of National Academy of Sciences of Ukraine, Dnipro, Ukraine

3 - Private Joint-Stock Company "DTEK”, Kyiv, Ukraine

\title{
PREDICTABILITY OF A SMALL-AMPLITUDE DISTURBANCE OF COAL SEAMS IN WESTERN DONBAS
}

Purpose. To identify development regularities of a small-amplitude disturbance in terms of typical Western Donbas mine fields and to define the most efficient tendencies of its prediction.

Methodology. The methods include analysis, systematization, generalization, and statistical processing of geological and geophysical data; probability analysis.

Findings. Such parameters of small-amplitude breakings as amplitudes, slope angles, and length of the disturbances have been geometrized within the fields of Stepova and Yuvileina mines of Pershotravenske Mine Office (MO). The abovementioned helped to develop the statistical distribution of the values. Zonality of the small-amplitude disturbances of coal seams has been determined for the fields of the mines. Parameters of the zones are continuous, which made it possible to extrapolate them to the undisturbed shares of the mine fields. Statistical processing of the data, concerning characteristics of small-amplitude disturbances, became a basis for hypothesizing on the theoretical probabilistic distribution of the values, which helped to predict probable amplitude and length of disturbances within the undisturbed shares of the mine fields. Log data of expendable wells were used to support the prediction results. Caliper logging, showing tectonic disturbances, has been defined as the most informative log index in the context of geological conditions of Yuvileina mine. The log data confirm the prediction with the use of the disturbed area extrapolation.

Originality. It has been proved that the small-amplitude disturbances within mine fields of Pershotravenske MO form persistent areas demonstrated steadily in the log data. Among other things, logging is the most informative log index demonstrating tectonic disturbances for the geological conditions of Yuvileina mine. Such geometrical parameters of the disturbances as amplitude and length are subject to the exponential rule of the probability distribution, making it possible to predict the most possible values of the amounts where new stopes are planned for operation. The information concerning disturbance parameters of a coal seam helps to predict the complexity of mining of certain sites of a mine field.

Practical value. It has been identified that in terms of the fields of Pershotravenske MO, efficient prediction of small-amplitude disturbance of coal seams should involve the integration of geological (zone extrapolation) and geophysical (logging) methods. The analysis of log data of exploration wells within the areas where extrapolation recorded the highest probability of the smallamplitude disturbance formation provides the early decisions as for the efficiency of the site mining to develop the required engineering solutions, and to predict the coal grade deterioration.

Keywords: Western Donbas, coal deposits, small-amplitude disturbances, zonality, logging, caliper logging

Introduction. Disturbances of coal seams, whose amplitude is less than $10 \mathrm{~m}$, belong to the small-amplitude ones. They cannot be detected during geological prospecting, and they are not involved during mining engineering. When mine workings come across with such a disturbance, it is an unexpected event resulting in significant negative impacts such as remounting of the powered mining systems [1] and extra power consumption during operation of cutting mechanisms under emergency conditions [2], in the mine workings flooding, and a rockburst initiation [3]. Geological faults cause variations of a natural stress field [4] producing additional load on the supports of roadways [5]. Thus, the problem of reliable prediction of small-amplitude disturbances is the topical one.

Literature review. Numerous scientific sources concern the problem of small-amplitude tectonic fissures of coal seams and their effect on mining and geological conditions as well as the development of methods for their prediction. Paper [6] represents the results of the analysis of small tectonics effect on the rock characteristics and methane deposit origination. Prediction tendencies may be divided into geological [7], geophysical [8], empirical [9], tectonophysical [10], physiochemical, and modeling [11] ones. Different methods experience their development in the context of each prediction tendency. For instance, geological tendency applies analogy methods; methods of breaking-folding connection [12]; methods of

(C) Prykhodchenko V.F., Shashenko O.M., Sdvyzhkova O. O., Prykhodchenko O. V., Pilyugin V. I., 2020 lithological control [13]; analysis of core fracturing; analysis of disturbance zonality [14], and others.

Geophysical prediction methods are rather various. Seismics [15] and well logging are considered as the most promising ones. Methods evaluating the intensity of small-amplitude disturbances; tectonophysical methods (determining mechanisms of the Earth's crust area formation), and different modeling methods (i.e. optical, graphical, and mathematical) also have been proposed.

Unsolved aspects of the problem. The available prediction methods of a small-amplitude tectonic disturbance cannot give reliable results for different mining and geological conditions.

The problem definition. It is required to define geological regularities of the small-amplitude disturbance progress to substantiate efficient use of prediction methods for the specific mining and geological conditions as well as for adaptation and integration of the methods.

Description of the methods. The research methods are based upon analysis, systematization, generalization, and statistical processing of geological and geophysical information. The authors' methods to digitalize logging diagrams have been developed.

Results. Prediction of a small-amplitude tectonic disturbance is a complicated problem of a mining geology. Drilling operations cannot detect such disturbances with less than 10 m amplitudes at a geological prospecting stage. Thus, methods to predict such disturbances are under rapid development. The methods rely upon the analysis of the varied indirect information. 
Small-amplitude disturbances of coal seams in Donbas can be divided into two groups: disturbances connected directly with regional tectonic stresses; and disturbances connected with the local redistribution of regional tectonic stresses.

Redistribution of regional tectonic stresses may depend upon large-amplitude faults; folding (either large or local); lithological nonhomogeneity of the carbonous formation (thinning of bodies of different rocks within roofs of coal seams; thinning of sandstone bodies within a parting, and the total lithology influence on the disturbance intensity).

Genetic types of disturbances should be taken into consideration while developing their prediction methods. Some or other genetic types of small-amplitude disturbances prevail for different geological conditions in different geological and industrial Donbas areas.

Small-amplitude disturbances, corresponding to the undeveloped large disturbances as well as the areas associated with large faults, dominate in Pavlohrad-Petropavlivka geological and industrial area of Donbas. Sometimes, it is possible to observe disturbances connected with local folding and with lithological inhomogeneity of the carbonous formation. These features should be involved while developing prediction methods for small-amplitude tectonic disturbances in terms of the specific geotectonic conditions. There are cases when the use of the methods, based upon the analysis of small-amplitude disturbance genesis (i.e. intensity of large-amplitude tectonic disturbance; local folding; and lithological nonhomogeneity), cannot help us predict categorically. If so, then it is necessary to use two prediction methods at least to verify the obtained results.

There are many approaches to predict a small-amplitude tectonic disturbance of coal seams. The approaches are based on different principles. Various prediction tendencies are known: geological, geophysical, empirical, tectonophysical, physiochemical, and modeling. The same prediction method may be referred to in several groups. For instance, geological methods are closely connected with empirical methods, tectonophysical, and others [16].

Among other things, the direct prediction follows thorough geometrization of small-amplitude disturbances within the mine fields, predicting intensive disturbance zones at the minedout sites and systematization of data concerning disjunctive parameters. Paper [17] outlines partially such an approach. In the context of Stepova and Yuvileina mine fields, several zones have been separated conditionally which are outlined by large and average tectonic disturbances (Prodolnyi fault, Brahynivskyi fault, and Petropavlivskyi fault as well as apophyses of the faults). It has been identified that in terms of each of the zones, small-amplitude disturbances are localized in the shape of ribbons with $70-80 \mathrm{~m}$ width stretching through the zone at $50-65^{\circ}$ angle to the large faults. Statistical analysis has shown that on the whole, in terms of the separated zones, average amplitude values vary from 0.3 to $1.7 \mathrm{~m}$; relative to the average value, a variation of amplitude values is $70-80 \%$. Such a significant data spread is compatible with the physical content of the variable under analysis, i. e. disturbance amplitude. According to a form of relative frequency histogram (Fig. 1), it is possible to hypothesize about the exponential rule of the value distribution [18] being described by the differential function (density)

$$
f(x)=\lambda e^{-\lambda x} \quad \forall x \in(0,+\infty),
$$

where $X$ is a random variation; and $\lambda$ is a distribution parameter that should be identified according to the statistical data.

The average value of the disturbance length is within the range of $0.5-1.1$ of a longwall length, i.e. they are $150-300 \mathrm{~m}$ with $80-85 \%$ variation. As for the variable, taking into account histogram type of the relative frequencies (Fig. 2), it is possible to hypothesize about the exponential rule of distribution being essentially asymmetrical, and for which $\lambda$ parameter is defined using a method of moments: $\lambda=\frac{1}{\bar{x}^{*}}$, where $\bar{x}^{*}$ is a mean of the statistical set. Among other things, in the context of the small-average disturbance zone, determined within the mine field, a parameter of the exponential distribution $\lambda$ is 2.0 for the disturbance amplitude and 1.85 for the disturbance length.

It is a typical feature that even "short" disturbances with $30-60 \mathrm{~m}$ length are grouped in ribbons crossing the panel being mined, complicating in such a way the coal seam mining with the help of a longwall. In some cases, it is possible to predict the continuation of the formed tectonic ribbon to the sites just planned for mining. The ribbon, formed from disturbances, stretches to Petropavlivskyi fault, crosses it, and stretches further, to Prodolnyi fault. It should be assumed that the ribbon may continue invertedly to Brahynivskyi fault, crossing the mine field share where the coal seam has not been mined by longwalls. However, such data extrapolation is not always possible. Analysis of the disjunctive zonality of Pershotravenske MO field has shown that in the majority of cases, the impact of large faults distorts regularities of small-amplitude disturbance ribbons.

To predict a small-amplitude disturbance in terms of insufficient reliability of geological prognoses and to control the prognoses under the conditions of Pavlohrad-Petropavlivka geologic and industrial Donbas region, we propose to apply the data of geophysical exploration of expendable wells (GEW).

The standard set of GEW methods in the process of well analysis within coal deposits includes: well caliper logging; logging of electric resistance using potential sondes; logging of electric resistance using gradient sondes; logging of arbitrary polarization potentials; gamma-ray logging; and gammagamma density logging. Acoustic logging has been used since the 1980s. Fewer GEW methods were applied in wells drilled in the 1950-1960s.

Lithological segmentation and correlation of a section of carbonous formations are the key problems being solved in the process of coal deposit exploration with the help of a standard set of geophysical studies of wells. However, indices of the standard GEW involve additional information too; namely, it concerns tectonic disturbance of coal and enclosing rocks. Actually, all methods of the standard logging within coal deposits record the disturbance in a certain manner. Specifically, a well diameter increases $(\Delta d)$ along with the intensity of scattered gamma radiation $(J \gamma \gamma)$ within the disturbed zones where strength is decreased, and rock fissuring is increased. Saturation by the mineralized deposit water results in the decreased

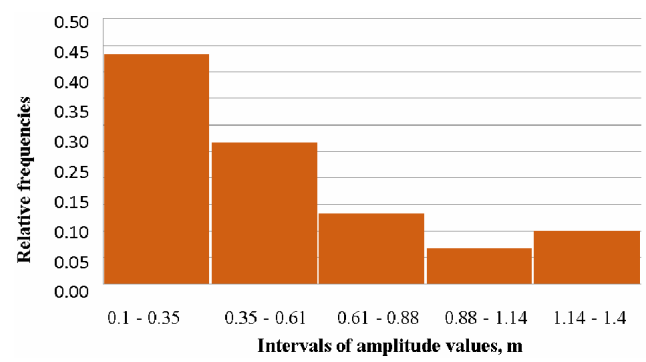

Fig. 1. Frequency histogram for disturbance amplitude within a small-amplitude disturbance zone

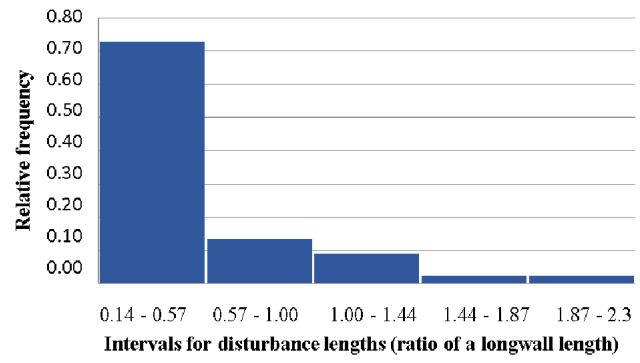

Fig. 2. Frequency histogram for a disturbance length (ratio of a longwall length) within a small-amplitude disturbance zone 
electric resistance of the rocks (measured by potential and gradient sondes); and conversely, in-gassing results in the increased electric resistance.

Logging diagrams of expendable wells within longwalls Nos. 122, 124, 126, and 128 were processed with the use of GEW data for the fields of Stepova and Yuvileina mines to evaluate prediction potential of the disturbed zones.

The research was carried out using the wells drilled in the 1970s and later. The wells, drilled earlier, were not involved due to the low quality of logging diagrams. Logging diagrams of ten wells (namely, Nos. 14145, 14170, 14183, 14201, 14337, $14653,14655,14704,1260 \mathrm{p}$, and 1323p) were processed within the mined-out area of $c_{6}$ coal seam. Wells Nos. 14170, 14183, 14337,14655 , and 14704 are located within the undisturbed parts of the coal seam. Other wells are within the disturbed parts of the seam. Namely, 14653 and 1323p wells are inside the zones of small-amplitude tectonic disturbances; 14145 well is inside Petropavlivskyi fault, and 14201 and 1260p wells are inside the influence zone of Petropavlivskyi fault apophyse.

The methods to process logging diagrams, proposed by the authors, include data transfer from the analog form to a digital one; determination of variability of relative indications of the parameters; and data comparison of tectonically disturbed and undisturbed zones. Two most informative parameters, obtained as a result of activities within Dniprovska mine field, were selected from six parameters of the standard logging. The parameters are as follows: logging data of electric resistance of rocks by a potential sonde and data by the well caliper logging.

Metering interval was $1 \mathrm{~m}$ within the sites of the section of a well with stable GEW index parameters and consistent lithology. Calculations were added by the characteristic variability points inside the sites with unstable parameters. It should be mentioned that parameter variability is greater for a well located within the disturbed zone. Figs. 3 and 4 demonstrate the logging diagram of a well No. 14170 drilled in the undisturbed zone and a well No. 1323p drilled in the disturbed zone.

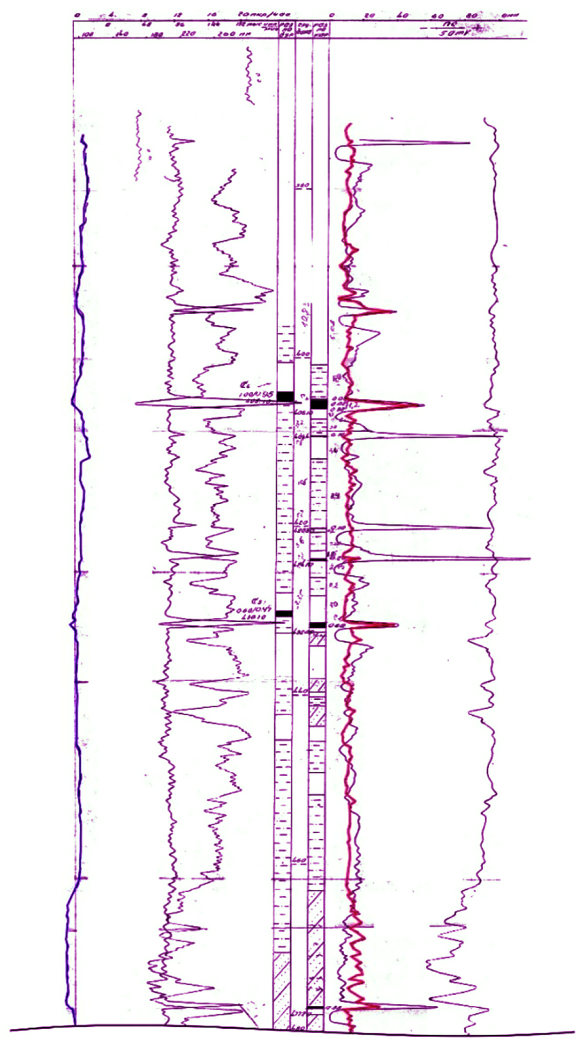

Fig. 3. Logging diagram of well No.14170 (undisturbed zone) Green is caliper logging; and red is electric resistance

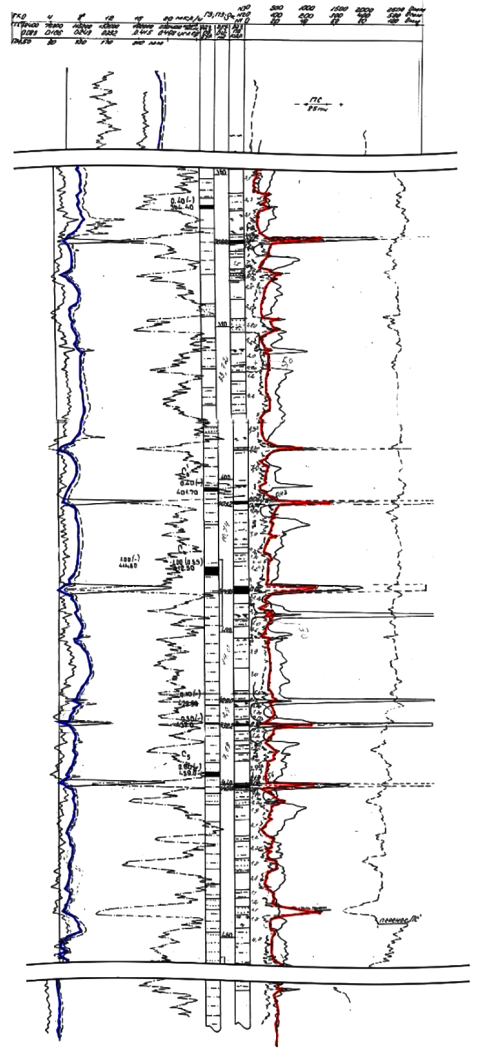

Fig. 4. Logging diagram of well 1323p (disturbed zone)

Green is caliper logging, and red is electric resistance

Tables 1 and 2 show exceed in the studied GEW parameters over the nominal ones for a well drilled within the undisturbed zone and a well drilled within the disturbed zone.

Such exceed in a well parameter over the nominal one characterizes disturbance degree of the carbonous formation varying for different lithological rock types. Specifically, in terms of hard sandstones, the excess is quite less to compare with argillites and siltstones for wells in the disturbed as well as in the undisturbed zones. In this context, the average well diameter is larger for each rock lithotype within the disturbed zone. On the whole, the relative deviation of electric resistance values is greater inside the wells within the disturbed zone. Tables 3 and 4 demonstrate average deviations of geophysical parameters for each analyzed well both within the undisturbed and disturbed shares of $c_{6}$ coal seam of Yuvileina mine field.

Tables 3 and 4 compare relative deviations of geophysical parameters for the undisturbed and disturbed shares of $c 6$ coal seam of Pershotravenske MO field.

Table 1

Excess in GEW parameters to compare with nominal ones for a well within the mined out share of c6 seam (undisturbed zone) of Yuvileina mine field (longwall No. 128). Well No. 14170

\begin{tabular}{|l|c|c|}
\hline Lithological type & $\begin{array}{c}\text { Relative deviation of } \\
\text { the well diameter from } \\
\text { its design value, } \%\end{array}$ & $\begin{array}{c}\text { Relative } \\
\text { resistance } \\
\text { deviation } \rho, \%\end{array}$ \\
\hline Argillite & 1.06 & 6.53 \\
\hline Siltstone & 1.25 & 7.35 \\
\hline Sandstone & 0.9 & 8.12 \\
\hline $\begin{array}{l}\text { In terms of all the } \\
\text { lithological types }\end{array}$ & 1.15 & 7.06 \\
\hline
\end{tabular}


Table 2

Excess in GEW parameters to compare with nominal ones for a well within the mined out share of $\mathrm{c} 6$ seam (disturbed zone) of Yuvileina mine field (longwall No. 128). Well No. $1323 \mathrm{p}$

\begin{tabular}{|l|c|c|}
\hline Lithological type & $\begin{array}{c}\text { Relative deviation of the well } \\
\text { diameter from its design } \\
\text { value, \% }\end{array}$ & $\begin{array}{c}\text { Relative } \\
\text { resistance } \\
\text { deviation } \rho, \%\end{array}$ \\
\hline Argillite & 4.92 & 10.05 \\
\hline Siltstone & 4.96 & 10.64 \\
\hline Sandstone & 2.99 & 11.00 \\
\hline Limestone & 4.05 & 11.54 \\
\hline $\begin{array}{l}\text { In terms of all the } \\
\text { lithological types }\end{array}$ & 4.83 & 10.43 \\
\hline
\end{tabular}

Table 3

Comparison of relative deviation of a well diameter (\%) for the undisturbed and disturbed shares of $c 6$ coal seam of Pershotravenske MO field (longwalls Nos. 122, 124, 126, and 128)

\begin{tabular}{|l|c|c|c|}
\hline $\begin{array}{c}\text { Lithological } \\
\text { type }\end{array}$ & $\begin{array}{c}\text { Disturbed } \\
\text { zone }\end{array}$ & $\begin{array}{c}\text { Undisturbed } \\
\text { zone }\end{array}$ & $\begin{array}{c}\text { Excess in the } \\
\text { values, times }\end{array}$ \\
\hline Argillites & 3.93 & 1.90 & 2.06 \\
\hline Siltstone & 4.08 & 1.64 & 2.49 \\
\hline Sandstones & 2.72 & 1.15 & 2.36 \\
\hline Average & 3.68 & 1.56 & 2.30 \\
\hline
\end{tabular}

Table 4

Comparison of relative resistance deviations $\rho(\%)$ for the undisturbed and disturbed shares of $c 6$ coal seam of Yuvileina mine field (longwalls Nos.122, 124, 126, and 128)

\begin{tabular}{|l|c|c|c|}
\hline $\begin{array}{c}\text { Lithological } \\
\text { type }\end{array}$ & $\begin{array}{c}\text { Disturbed } \\
\text { zone }\end{array}$ & $\begin{array}{c}\text { Undisturbed } \\
\text { zone }\end{array}$ & $\begin{array}{c}\text { Excess in the } \\
\text { values, times }\end{array}$ \\
\hline Argillites & 9.16 & 7.35 & 1.25 \\
\hline Siltstone & 9.90 & 8.76 & 1.13 \\
\hline Sandstones & 12.35 & 10.36 & 1.19 \\
\hline Average & 10.78 & 8.82 & 1.22 \\
\hline
\end{tabular}

For each lithological rock type and in the context of the whole well, relative diameter increase in the tectonic disturbed zones is 2.3 times more to compare with the undisturbed zones.

A relative increase in electric resistance is observed for all lithological types measured by a potential sonde within the zones disturbed tectonically. The average increase is $22 \%$ within $100 \mathrm{~m}$ interval.

Hence, caliper logging of the expendable wells, demonstrating tectonic disturbance for geological conditions of Stepova and Yuvileina mines, is a rather efficient index. The difference in indices for the disturbed and undisturbed zones is more than twice.

Logging diagrams of expendable wells drilled in the 1970s and later were processed for the undisturbed share of $c 6$. Such GEW parameter as caliper logging was considered, which reflected in full a tectonic disturbance within the mined-out area of the coal seam.

The ratio of a well diameter deviation between average well diameter deviations within the undisturbed zone was considered for each of the lithotypes. Double excess in the analyzed parameter over an average one was assumed as a reference criterion to the disturbed zone. If the excess over the average values was more than twofold for all the three lithotypes, then the well was considered as the disturbed one. If the excess over the average values was less than twofold for all the three lithotypes, then the well was considered as the undisturbed one. If the excess over the average values was less than twofold for all some lithotypes, and more than twofold for others, then the well was considered as the probably disturbed one.

Fig. 5 demonstrates prediction results for the disturbed zones in terms of GEW data as well as a small-amplitude disturbance zone separated using extrapolation. Well 14574 verifies the availability of the separated zone.

The conclusions coincide with the results of the abovementioned prediction of disjunction localization based upon the determined zonality of small-amplitude disturbances. Relying upon the formulated statistical population of amplitude values and length of the disturbances as well as upon the hypothesis concerning theoretical distribution law, it is possible to predict such disturbance parameters within the undisturbed share of a coal seam as disturbance amplitude will not be more than $1.5 \mathrm{~m}$ (with a probability of 0.95 ) and the disturbance length will not be more than $1.62 \mathrm{~m}$ of a longwall length (i.e. $486 \mathrm{~m}$, if the longwall length is $300 \mathrm{~m}$ ).

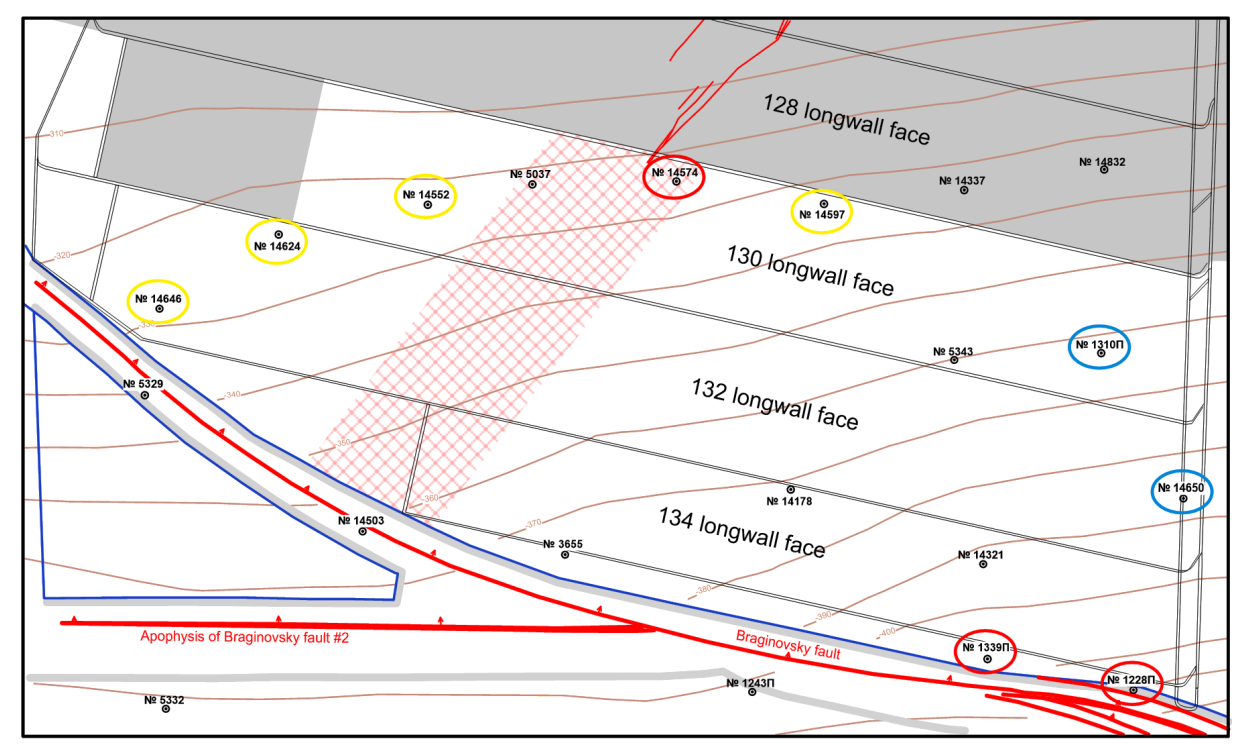

Fig. 5. Tectonic disturbances according to GEW data of expendable wells of c6 seam of Yuvileina mine field:

are wells within the disturbed zones; is the prediction zone of a small-amplitude disturbance 
Prediction of quantative parameters of small-amplitude disturbances is extremely important to classify the rock mass in terms of its disturbance degree [19]; to model geomechanical processes during coal mining [20], and to evaluate the efficiency of coal seam mining within the disturbed zones.

Conclusions. Thus, there are many prediction methods for a small-amplitude disturbance (i.e. geological, geophysical, empirical, tectonophysical, physiochemical, modeling, and others). However, neither of them is a universal method to make accurate predictions.

Geological methods (i.e. separation of the disturbed zones with their further extrapolation) and geophysical methods (i. e. methods, based upon analysis of logging data of expendable wells) are the most efficient for the conditions of Pavlohrad-Petropavlivka geological and industrial region in Donbas.

The pronounced zones, extrapolated to the undisturbed share of coal seam $c_{6}$ of Yuvileina mine field, have been identified.

It has been found that caliper logging is the most informative index to predict a small-amplitude disturbance for the conditions of Pershotravenske MO.

Data on geophysical analysis of wells support the predicted zone of small-amplitude disturbances (longwalls Nos. 130, 132, and 134).

Acknowledgments. The results have been obtained within the framework of the project sponsored by DTEK Pavlohradvuhillia PJSC. The authors highly appreciate assistance in the research by the authorities and geological survey of Pershotravenske $\mathrm{MO}$

\section{References.}

1. Dychkovskyi, R., Lozynskyi, V., Saik, P., Petlovanyi, M., Malanchuk, Y., \& Malanchuk, Z. (2018). Modeling of the disjunctive geological fault influence on the exploitation wells stability during underground coal gasification. Archives of Civil and Mechanical Engineering, 18(4), 1183-1197.

2. Tkachov, V., Bublikov, A., \& Gruhler, G. (2018). Automated stabilization of loading capacity of coal shearer screw with controlled cutting drive. Theoretical and Practical Solutions of Mineral Resources Mining, 465-477. https://doi.org/10.1201/ b19901-82.

3. Prykhodchenko, V.F., Sdvyzhkova, O.O., Khomenko, N. V., \& Tykhonenko, V. V. (2016). Effect of time-transgressive faults upon methane distribution within coal seams. Naukovyi Visnyk Natsionalnoho Hirnychoho Universytetu, (1), 31-35.

4. Dixit, C. N., Hanks, L. C., Wallace, K.W., Ahmadi, M., \& Awoleke, O. (2017). In situ stress variations associated with regional changes in tectonic setting, northeastern Brooks Range and eastern North Slope of Alaska. AAPG Bulletin, 101(3), 343-360. https://doi.org/10.1306/08051616013.

5. Diomin, V. F., Khalikova, E. R., Diomina, T.V., \& Zhurov, V.V. (2019). Studying coal seam bedding tectonic breach impact on supporting parameters of mine workings with roof bolting. Naukovyi Visnyk Natsionalnoho Hirnychoho Universytetu, (5), 16-21. https://doi.org/10.29202/nvngu/2019-5/5. 6. Prykhodchenko, V., Khomenko, N., Zhykalyak, M., Prykhodchenko, D., \& Tokar, L. (2019). Influence of local orogeny and reservoir characteristics of enclosing rocks on the location of gas traps within the coal bearing deposits. Naukovyi Visnyk Natsionalnoho Hirnychoho Universytetu, (5), 11-15. https://doi.org/10.29202/nvngu/2019-5/1.

7. Bezruchko, K., Diachenko, N., \& Urazka, M. (2018). Influence of the Western Donbas share dislocation zone on the formation of gas accumulations in coal-bearing sediments. Heodynamika, 1(24), 27-39. https://doi.org/10.23939/ jgd2018.01.027.

8. Dubitskaya, M. S., \& Klimenko, D. V. (2015). Geoacoustic forecast of small-amplitude tectonics of coal-bearing massif during mining of coal seams with plow complexes. Journal of Kryvyi Rih National University, 39, 34-38.

9. Shurygin, D. N., \& Efimov, D. A. (2013). Methods for identifying homogeneous geological regions of a mine field to predict its small-amplitude disturbance. University News. North Caucasus region. Engineering, 1, 128

10. Steven A. F. Smith, Andrea Bistacchi Thomas, M. Mitchell, \& Giulio Di Toro (2013). The structure of an exhumed intraplate seismogenic fault in crystalline basement, Tectonophysics, 599, 29-44. https://doi.org/10.1016/j.tecto.2013.03.031.

11. Shurygin, D. N. (2013). Mathematical modeling of the carbon-bearing stratum and forecasting of geological conditions. Mining Information and Analytical Bulletin, 1(201).

12. Richard C. Alt, \& Mark D. Zoback (2017). In Situ Stress and Active Faulting in Oklahoma. Bulletin of the Seismological Society of America, 107(1), 216-228. https://doi. org /10.1785/0120160156.

13. Lukinov, V., Prykhodchenko, V., Tokar, L., \& Prykhodchenko, O. (2014). Mining and geological conditions of methane redistributions within the undermining coal-rock massif. Progressive Technologies of Coal, Coalbed Methane, and Ores Mining, 317-325. https://doi.org/10.1201/b17547.

14. Ning-hua Chen, Jin-jin Dong, Jian-yu Chen, Chuan-wan Dong, \& Zhong-yue Shen (2014). Geometry and emplacement of the Late Cretaceous mafic dyke swarms on the islands in Zhejiang Province, Southeast China: Insights from highresolution satellite images. Journal of Asian Earth Sciences, 79(A), 302-311. https://doi.org/10.1016/j.jseaes.2013.10.001.

15. Shashenko, A. N., Zhuravlev, V. N., Sdvizhkova, Ye.A., \& Dubitska, M. S. (2015). Forecast of disjunctives based on mathematical interpretation of acoustic signal phase characteristics. Naukovyi Visnyk Natsionalnoho Hirnychoho Universytetu, (2), 61-66.

16. Kalinchenko, V.V., Shurygin, D. N., \& Efimov, D.A. (2013). Methods for predicting small-amplitude disturbance of coal seams. Coal, 11(1052), 74-45.

17. Shabelnikov, S. (2017). Prediction of localities of smallamplitude geological faults in coal mines. Gornyi Zhurnal, 12. https://doi.org/10.17580/gzh.2017.12.04S.

18. Shcherbakov, P., Klymenko, D., \& Tymchenko, S. (2017). Statistical research of shovel excavator performance during loading of rock mass of different crushing quality. Naukovyi Visnyk Natsionalnoho Hirnychoho Universytetu, (1), 49-54.

19. Babets, D. V. (2018). Rock mass strength estimation using structural factor based on statistical strength theory. Solid State Phenomena, 277, 111-122. https://doi.org/10.4028/www. scientific.net/SSP.277.111.

20. Kononenko, M., Khomenko, O., Sudakov, A., Drobot, S., \& Lkhagva, T. (2016). Numerical modelling of massif zonal structuring around underground working. Mining Of Mineral Deposits, 10(3), 101-106. https://doi.org/10.15407/mining10.03.101.

\section{Можливість прогнозування малоамплітудної розривної порушеності вугільних пластів у Західному Донбасі}

\section{В. Ф. Приходченко ${ }^{1}$, О. М. Шашенко ${ }^{1}$} О. О. Сдвижкова ${ }^{1}$, О. В. Приходченко ${ }^{2}$ В. І. Пілюгін ${ }^{3}$

1 - Національний технічний університет «Дніпровська політехніка», м. Дніпро, Україна, e-mail: prykhodchenko.v.f@ nmu.one

2 - Інститут геотехнічної механіки імені С. М. Полякова НАН України, м. Дніпро, Україна

3 - ПАО «ДТЕК», м. Київ, Україна

Мета. Визначити закономірності розвитку малоамплітудної розривної порушеності на прикладі типових шахтних полів у Західному Донбасі та встановити найбільш ефективні напрямки ії прогнозу. 
Методика. Аналіз, систематизація, узагальнення та статистична обробка фондової геологічної й геофізичної інформації, імовірнісний аналіз.

Результати. Виконана геометризація параметрів малоамплітудних розривів: амплітуди, кута падіння, довжини розривів у межах полів шахт «Степова» та «Ювілейна» ШУ «Першотравенське», що надало змогу побудувати статистичні розподіли вказаних величин. Встановлена зональність у розповсюдженні малоамплітудних розривів вугільних пластів для полів указаних шахт. Параметри зон є витриманими, що надало можливість їх екстраполяції на невідпрацьовані частини шахтопластів. На основі статистичної обробки даних щодо характеристик малоамплітудних порушень висунута гіпотеза про теоретичний імовірнісний розподіл цих величин, що дало змогу спрогнозувати ймовірну амплітуду й довжину розривів на невідпрацьованих частинах шахтопластів. Для підтвердження результатів прогнозування були використані дані каротажу геологорозвідувальних свердловин. Встановлено, що для геологічних умов шахти «Ювілейна» найбільш інформативним показником каротажу, що відображає тектонічну порушеність, є кавернометрія. Дані каротажу підтверджують прогнозування із застосуванням екстраполяції порушених зон.

Наукова новизна. Доведено, що малоамплітудні розриви на полях шахт ШУ «Першотравенське» утворюють витримані зони, які впевнено відображаються в даних каротажу, зокрема, найбільш інформативним показником каротажу, що відображає тектонічну порушеність для геологічних умов шахти «Ювілейна», є кавернометрія. Геометричні параметри розривів - амплітуда та довжина - підпорядковуються показниковому закону розподілу ймовірностей, що дозволяє надати прогнозування найбільш вірогідних значень указаних величин на ділянках, де планується введення в експлуатацію нових очисних вибоїв. Відомості щодо параметрів порушеності вугільного пласта дозволяють прогнозувати ступінь складності відпрацювання певних ділянок шахтного поля.

Практична значимість. Встановлено, що для прогнозу малоамплітудної порушеності вугільних пластів для умов полів шахт ШУ «Першотравенське» ефективним є комплексування геологічних (екстраполяція зон) і геофізичних (каротаж) методів. Аналіз даних каротажу розвідувальних свердловин у тих зонах, де екстраполяцією встановлена найбільша вірогідність формування смуг малоамплітудних порушень, дозволяє прийняти заздалегідь рішення щодо ефективності відпрацювання даної ділянки шахтного поля, розробити необхідні технічні рішення та прогнозувати втрати якості вугілля.

Ключові слова: Західний Донбас, вугільні пласти, малоамплітудні розриви, зональність, каротаж, кавернометрія

\section{Возможность прогнозирования малоамплитудной разрывной нарушенности угольных пластов в Западном Донбассе}

\author{
В. Ф. Приходченко ${ }^{1}$, А. Н. Шашенко ${ }^{1}$, \\ Е. А. Сдвижкова ${ }^{1}$, А. В. Приходченко ${ }^{2}$, В. И. Пилюгин ${ }^{3}$ \\ 1 - Национальный технический университет «Дне- \\ провская политехника», г. Днепр, Украина, e-mail: \\ prykhodchenko.v.f@nmu.one \\ 2 - Институт геотехнической механики имени С. М. По- \\ лякова НАН Украины, г. Днепр, Украина \\ 3 - ЧАО «ДТЭК», г. Киев, Украина
}

Цель. Определить закономерности развития малоамплитудной разрывной нарушенности на примере типовых шахтных полей в Западном Донбассе и установить наиболее эффективные направления ее прогноза.

Методика. Анализ, систематизация, обобщение и статистическая обработка фондовой геологической и геофизической информации, вероятностный анализ.

Результаты. Выполнена геометризация параметров малоамплитудных разрывов: амплитуды, угла падения, длины разрывов в пределах полей шахт «Степная» и «Юбилейная» ШУ «Первомайское», что дало возможность построить статистические распределения указанных величин. Установлена зональность в распространении малоамплитудных разрывов угольных пластов для полей указанных шахт. Параметры зон выдержаны, что дало возможность их экстраполяции на неотработанные части шахтопластов. На основе статистической обработки данных о характеристиках малоамплитудных нарушений выдвинута гипотеза о теоретическом вероятностном распределении этих величин, что позволило спрогнозировать возможную амплитуду и длину разрывов на неотработанных частях шахтопластов. Для подтверждения результатов прогнозирования были использованы данные каротажа геологоразведочных скважин. Установлено, что для геологических условий шахт «Юбилейная» наиболее информативным показателем каротажа, отражающим тектоническую нарушенность, является кавернометрия. Данные каротажа подтверждают прогноз с применением экстраполяции нарушенных зон.

Научная новизна. Доказано, что малоамплитудные разрывы на полях шахт ШУ «Первомайское» образуют выдержанные зоны, которые уверенно отражаются в данных каротажа, в частности, наиболее информативным показателем каротажа, отражающим тектоническую нарушенисть для геологических условий шахты «Юбилейная», является кавернометрия. Геометрические параметры разрывов - амплитуда и длина - подчиняются показательному закону распределения вероятностей, что позволяет давать прогнозирование наиболее вероятных значений указанных величин на участках, где планируется введение в эксплуатацию новых очистных забоев. Сведения о параметрах нарушенности угольного пласта позволяют прогнозировать степень сложности отработки определенных участков шахтного поля.

Практическая значимость. Установлено, что для прогноза малоамплитудной нарушенности угольных пластов для условий полей шахт ШУ «Первомайское» эффективным является комплексирование геологических (экстраполяция зон) и геофизических (каротаж) методов. Анализ данных каротажа разведывательных скважин в тех зонах, где экстраполяцией установлена наибольшая вероятность формирования полос малоамплитудных нарушений, позволяет принять заранее решения по эффективности отработки данного участка шахтного поля, разработать необходимые технические решения и прогнозировать потери качества угля.

Ключевые слова: Западный Донбасс, угольные пласты, малоамплитудные разрывы, зональность, каротаж, кавернометрия

Recommended for publication by I. O. Sadovenko, Doctor of Technical Sciences. The manuscript was submitted 27.12.19. 